\title{
KARAKTERISTIK FISIK MASSA AIR PERAIRAN TELUK TOMINI
}

\author{
Suwarso", Herlisman"), dan Wudianto")
}

\begin{abstract}
ABSTRAK
Teluk Tomini adalah perairan laut dalam dan bersifat semi tertutup, memiliki sumber daya ikan cukup besar yang dikelola oleh beberapa wilayah. Kajian tentang profil fisik massa air (suhu dan salinitas) Teluk Tomini yang didasarkan pada hasil pengukuran in situ pada musim timur di seluruh perairan (habitat pelagis) melalui transek secara sistimatik paralel pada beberapa strata kedalaman ini diharapkan dapat memberi keterangan tentang dinamika sumber daya beserta sifat biologinya. Pada musim timur, suhu permukaan terlihat lebih dingin di sebelah timur dan semakin hangat ke arah barat; massa air bersuhu dingin ini memiliki salinitas yang lebih tinggi. Secara umum, ada indikasi masuknya massa air dari Laut Maluku, terutama di kedalaman $>75 \mathrm{~m}$, yang menimbulkan terjadinya stratifikasi massa air di dalam teluk, baik secara vertikal maupun horisontal, dan membentuk suatu sistem perputaran massa air yang khas di dalam teluk. Hasil kajian pada habitat karang di sekitar Kepulauan Togian berdasarkan pada hasil pengukuran secara in situ pada musim barat juga dibahas.
\end{abstract}

\section{ABSTRACT: Physycal proflles of the water massess of Tomini Bay. By: Suwarso, Herlisman, and Wudlanto}

The Tomini Bay is a semi enclosed oceanic waters with have the high fish production which is managed by some district around it. The study on the physical profiles of water masses was in Tomini Bay based on the in situ measurement of the temperatures and salinity at east season in the whole areas (the pelagic habitats) through the sistematically parallel transect according to the depth. This supposed to examine the dynamics of the resource together with the biological characteristic. On the east season, the lower temperatures of the surface occurred in the eastern part of the bay (mouth) and than those were higher in the western part; these colder water masses are following by the higher salinity. Generally, the sign of the entry water mass seems to be coming from Mollucca Sea, particularly in the $>75 \mathrm{~m}$ depth, which built the water masses stratification within the bay, either vertically than horizontally, and form a specific water mass system of the bay. Study on the physycal profiles of water mass around rock habitats of Togian Islands was based on the in situ measurement in west season was also discussed.

\section{KEYWORDS: $\quad$ physicall oceanography, temperature, salinity, current, Tomini Bay, Togian Islands}

\section{PENDAHULUAN}

Teluk Tomini adalah salah satu teluk terbesar di Indonesia, Iuasnya sekitar $59.500 \mathrm{~km}^{2}$. Secara administratif, mencakup 3 propinsi dan 7 kabupaten atau kota dan terletak dalam kesatuan wilayah pengelolaan perikanan Teluk Tomini, Laut Maluku, dan Laut Seram. Perairan ini memiliki sumber daya ikan yang cukup besar, potensi sumber daya ikan pelagis diperkirakan 486.000 ton per th (83\%), di mana sebagian besar ( $80 \%$ ) di antaranya berupa ikan pelagis kecil (Anonymous, 2001); di pihak lain, potensi sumber daya ikan demersal (sebagian besar berupa ikan karang) diperkirakan 96.000 ton per th atau sekitar 16\%. Gugusan sekitar 56 pulau karang (Kepulauan Togian) terhampar di dalam kawasan teluk yang merupakan lingkungan terumbu karang dengan kekayaan biodiversitas yang tinggi termasuk berbagai jenis ikan karang; luas kawasan Kepulauan Togian sekitar $755,4 \mathrm{~km}^{2}$.

Perairan Teluk Tomini adalah laut dalam (oseanik) dengan kedalaman rata-rata $>1.500 \mathrm{~m}$, berbentuk sebagai corong yang terbuka ke arah timur dan berhubungan langsung dengan Laut Maluku, Teluk Tolo, dan Laut Sulawesi. Kondisi geografis demikian memberi konsekuensi terjadinya sirkulasi massa air di antara perairan di dalam teluk dengan perairan di sekitarnya.

Dalam tulisan ini diuraikan kajian oseanografi yang melibatkan karakter fisik massa air teluk pada habitat pelagis yang didasarkan pada hasil pengukuran secara in situ pada musim timur tahun 2003, serta pada habitat karang yang didasarkan pada hasil pengukuran secara in situ pada musim barat tahun 2004. Hasil kajian diharapkan dapat memberi keterangan tentang dinamika sumber daya ikan, sifat biologi, migrasi, agregasi, pemijahan dan tingkah laku lainnya dari gerombolan ikan serta tingkatan-tingkatan tropik (tropic leve/) pendukungnya yang secara keseluruhan merupakan informasi penting bagi pengelolaan perikanan. Di samping itu hasil kajian juga dapat bermanfaat bagi studi fisheries oceanography selanjutnya (Laevastu \& Hela, 1970).

\section{BAHAN DAN METODE}

\section{Lahan Studi}

Teluk Tomini terletak pada koordinat $120^{\circ} 15^{\prime}$ sampai dengan $125^{\circ} 15^{\prime}$ Bujur Timur dan $1^{\circ} 15^{\prime}$ Lintang Utara sampai dengan $1^{\circ} 23^{\prime}$ Lintang Selatan (Gambar

\footnotetext{
Peneliti pada Balai Riset Perikanan Laut, Jakarta
} 
1). Di bagian tengah perairan, pada kordinat $0^{\circ} 8 ' 21^{\prime \prime}$ sampai dengan $0^{\circ} 45^{\prime} 12^{\prime \prime}$ Lintang Selatan dan $121^{\circ} 33^{\prime} 21^{\prime \prime}$ sampai dengan 122 $23^{\prime} 36^{\prime \prime}$ Bujur Timur, terhampar gugusan dari 56 pulau yang termasuk Kepulauan Togian. Dasar teluk terdiri atas 2 cekungan geologi (cekungan Tomini dan cekungan Gorontalo) yang terbentuk akibat perekahan dan rotasi neogen dari Lengan Utara pada sekitar $5 \mathrm{Ma}$ (Hamilton, 1979; Walpersdorf et al., 1997). Di tepi barat cekungan dibatasi oleh sesar aktif Pulau Koro, di bagian timurnya dibatasi oleh sesar geser Gorontalo (Katili et al., 1973 In Burhanuddin et al., 2004), sedangkan di bagian tengah ke-2 cekungan muncul gunung api (Gunung Colo) yang aktif di Pulau Una-una (Kepulauan Togian). Dalam pandangan vertikal, profil cekungan berbentuk miring ke arah timur, di sebelah barat kedalamannya sekitar $2.000 \mathrm{~m}$ dan di sebelah timur (daerah sekitar mulut teluk) kedalamannya mencapai $4.000 \mathrm{~m}$. Peta batimetri Teluk Tomini disajikan pada Gambar 1.

Daerah sekitar Teluk Tomini memiliki bulan basah selama 7 sampai dengan 9 bulan dengan bulan kering selama 3 bulan. Curah hujan tidak merata dan berfluktuasi setiap bulan. Curah hujan yang tinggi pada umumnya terjadi antara bulan April sampai dengan Juli dan Oktober sampai dengan Nopember, curah hujan rendah terjadi pada bulan September dan bulan Desember sampai dengan Januari. Suhu udara berkisar antara 29,4 sampai dengan $30^{\circ} \mathrm{C}$. Tinggi gelombang bervariasi menurut musim, pada umumnya antara 1 sampai dengan $2 \mathrm{~m}$ dengan tinggi gelombang maksimum $(2 \mathrm{~m}$ ) terjadi pada musim timur (bulan Juni sampai dengan Agustus), sedangkan pada musim barat (bulan Desember sampai dengan Pebruari), musim peralihan barat ke timur (bulan
Maret sampai dengan Mei) dan peralihan timur ke barat (bulan September sampai dengan Nopember) tinggi gelombang dapat mencapai 1,5 m. Selain itu, dapat dijumpai gelombang ekstrim yang dapat terjadi pada akhir bulan Maret (2 sampai dengan 5,5 m), awal bulan Juni ( 2 sampai dengan $3 \mathrm{~m}$ ), awal bulan Agustus ( 1 sampai dengan $3 \mathrm{~m}$ ), awal bulan September ( 2 sampai dengan $6 \mathrm{~m}$ ), dan awal bulan Oktober (2 sampai dengan $3 \mathrm{~m}$ ) (Burhanuddin et al., 2004).

\section{Pengambilan Contoh dan Pengukuran}

Pengambilan contoh dilaksanakan melalui survei laut bersama dengan survei akustik; untuk habitat pelagis dengan menerapkan cruise berpola sistematik paralel (Gambar 2A) sehingga diharapkan dapat mewakili keseluruhan daerah penelitian, sedangkan untuk habitat karang dilakukan secara zig-zag pada lahan karang di sekitar Kepulauan Togian sampai dengan kedalaman 200 m (Gambar 2B). Survei laut di habitat pelagis dilaksanakan pada bulan Juli atau Agustus 2003 (musim timur) dengan menggunakan KM. Malalugis (91 GT); sedangkan survei di habitat karang dilaksanakan pada bulan Desember 2004 (musim barat) dengan menggunakan kapal nelayan KM. Cahaya Una-una (7 GT).

Parameter fisik perairan (suhu dan salinitas) diukur dengan menggunakan Current Meter Valeport plus CTD Seri 108/308, masing-masing pada 35 stasiun contoh di perairan Teluk Tomini (habitat pelagis) dan 15 stasiun contoh di sekitar Kepulauan Togian (habitat karang). Pengukuran dilakukan pada beberapa kedalaman standar sebagai berikut $5 \mathrm{~m}, 25$ m, 50 m, 75 m, 100 m, 150 m, 200 m, 250 m, dan 300 $\mathrm{m}$.

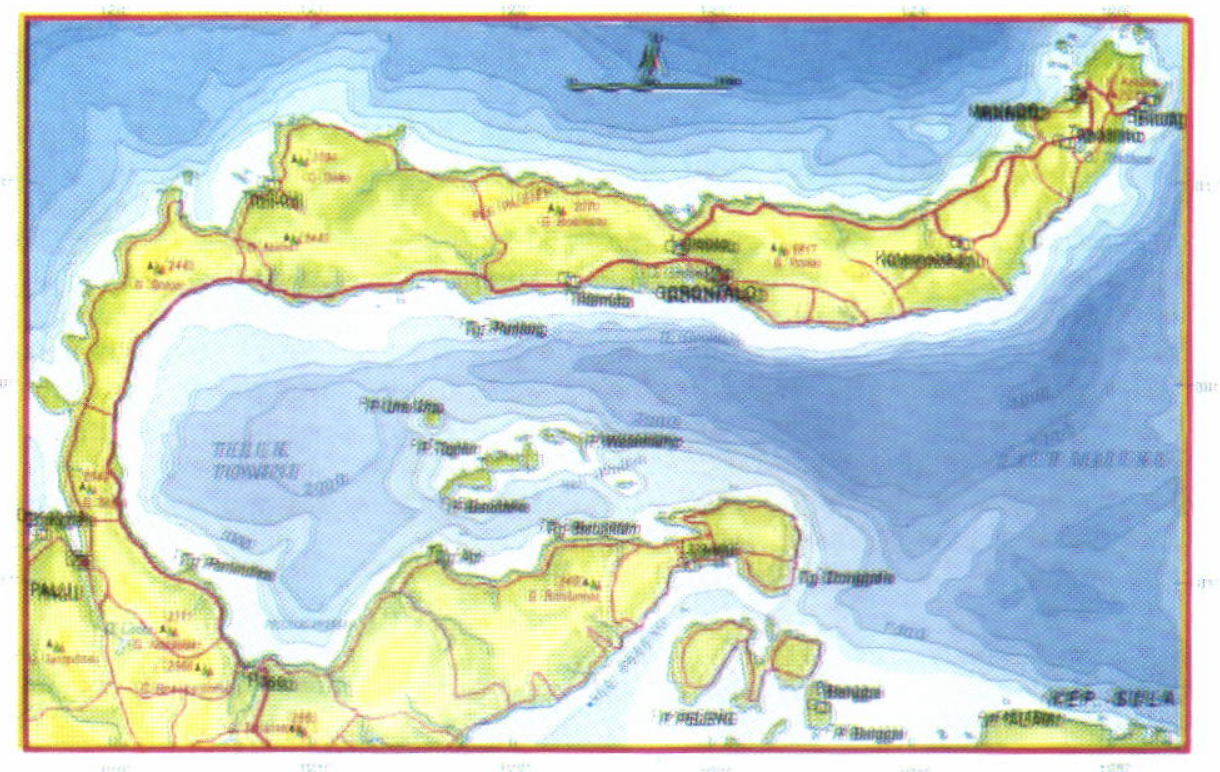

Gambar 1. Peta lokasi dan bathimetry Teluk Tomini.

Figure 1. Map and the bathymetry of Tomini Bay.

Source: Burhanuddin et al., 2004 


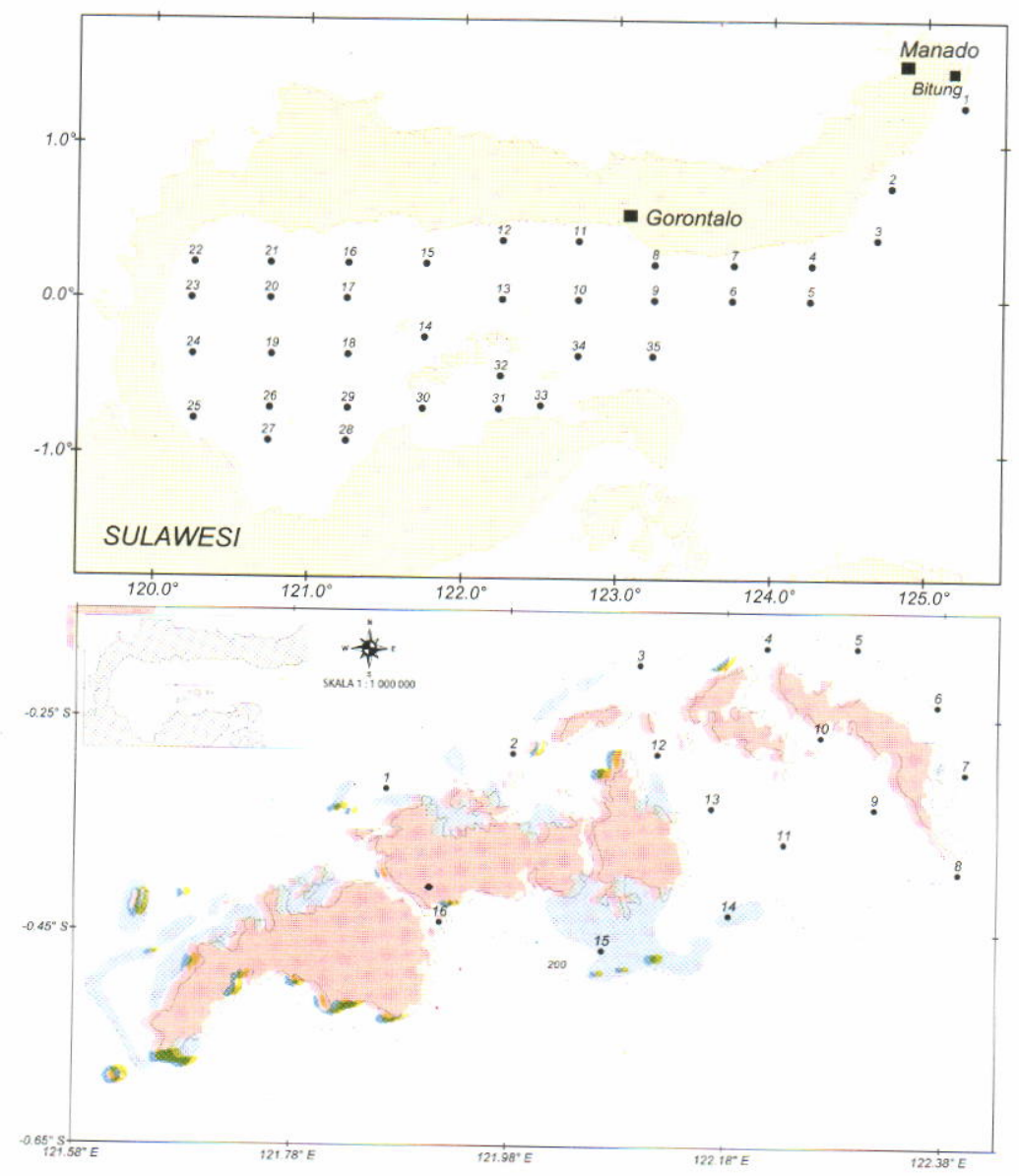

Gambar 2. Peta lokasi dan stasiun oseanografi pada habitat pelagis di Teluk Tomini (bulan Juli sampai dengan Agustus 2003, A) dan pada habitat karang di sekitar Kepulauan Togian (bulan Desember 2004, B).

Figure 2. Location and oceanographic station on the pelagic habitats of Tomini Bay (July/August 2003, A) and at rock habitats of around Togian Island (December 2004).

\section{Analisis Data}

Data oseanografi digambarkan dalam bentuk sebaran menegak (vertikal), mendatar (horisontal), dan melintang, yaitu untuk mempelajari tipe-tipe massa air yang ada dan pola sebarannya di daerah penelitian. Visualisasi dilaksanakan dengan bantuan software Excel dan Surfer (versi 8). Interpretasi untuk mencirikan karakteristik perairan dilakukan berdasarkan pada tipe-tipe massa air khusus yang umum dikenal.

\section{HASIL DAN BAHASAN}

\section{Karakteristik Lapisan Massa Air}

Hasil pengukuran pada bulan Juli atau Agustus 2003 (musim timur) menunjukkan suhu permukaan berkisar antara 27,5 sampai dengan $31,5^{\circ} \mathrm{C}$, salinitas antara 33,3 sampai dengan 35,3 psu (practical saliniy unit). Dalam transek vetikal (Gambar 3) lapisan tercampur (mixed layer) suhu (lapisan homogen suhu) pada musim timur pada umumnya berada sampai dengan kedalaman $50 \mathrm{~m}$, kecuali pada beberapa lokasi, stasiun 3,5 , dan 25 , lapisan ini sampai dengan kedalaman $75 \mathrm{~m}$. Meski secara umum lapisan homogen salinitas juga sama (Gambar 4), namun pada kondisi tertentu tidak terlihat lapisan tercampur salinitas dengan gradien salinitas yang tajam. Pola ini terlihat di stasiun 22 dan 23 (transek 1), stasiun 19 , 20 , dan 25 (transek 3 ) serta semua stasiun di transek 4. Gambaran tersebut di atas juga ditegaskan pada sebaran melintang suhu dan salinitas seperti pada Gambar 7 dan 8.

Di bawah lapisan tercampur terdapat lapisan termoklin yang pada umumnya ditemukan mulai kedalaman 50 sampai dengan $150 \mathrm{~m}$, kecuali pada 3 lokasi tersebut di atas (stasiun 3, 5, dan 25) (lihat Gambar 7 dan 8). Lebih dalamnya lapisan homogen di 3 stasiun tersebut diduga ditimbulkan oleh percampuran massa air yang disebabkan oleh angin sehingga mendorong lapisan mixed layer lebih ke 


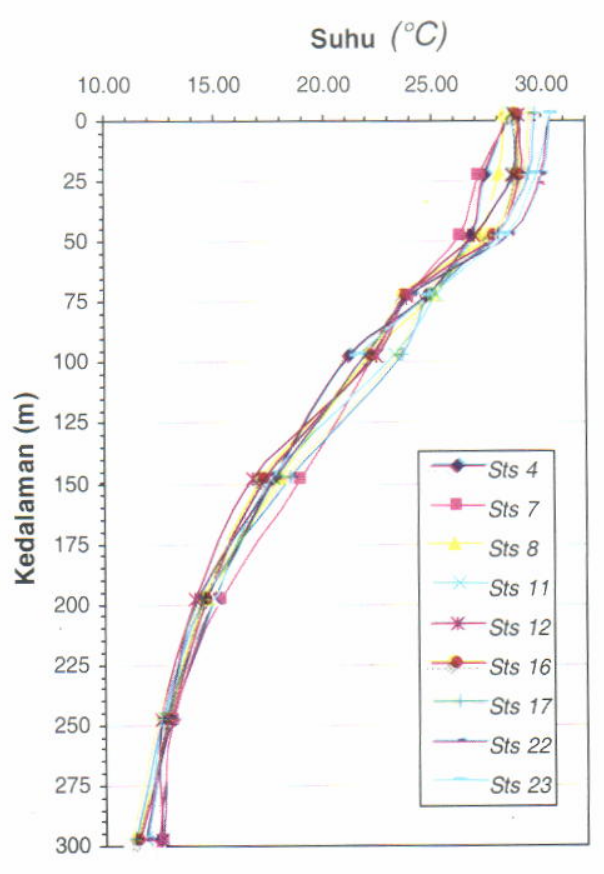

Transek 1

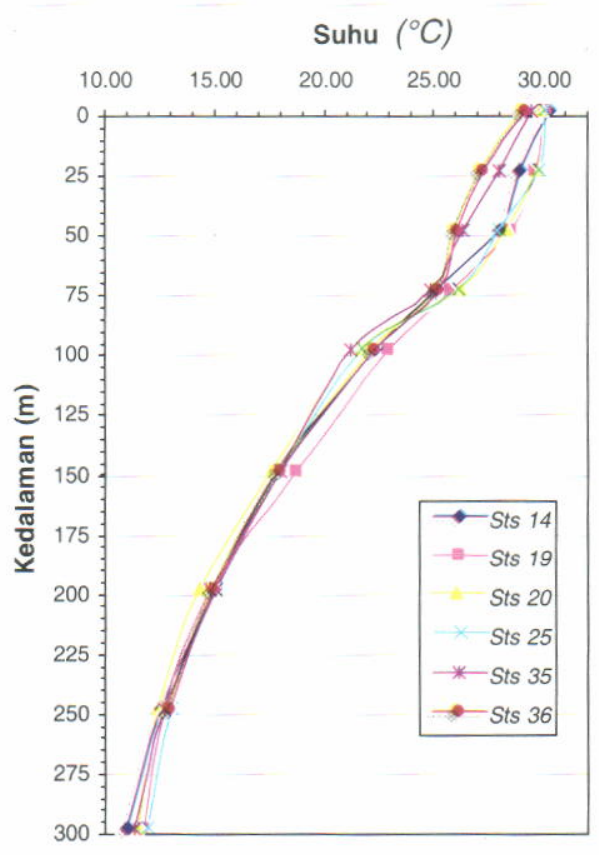

Transek 3

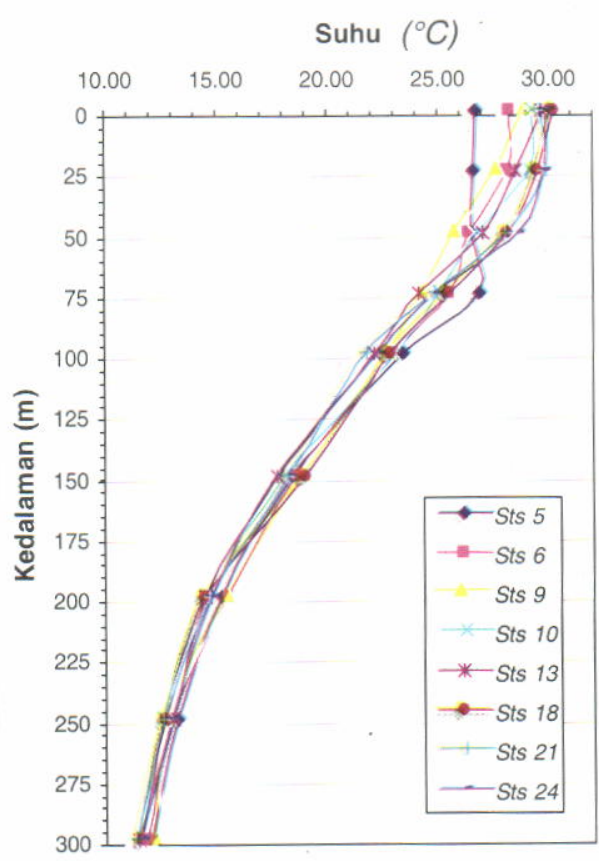

Transek 2

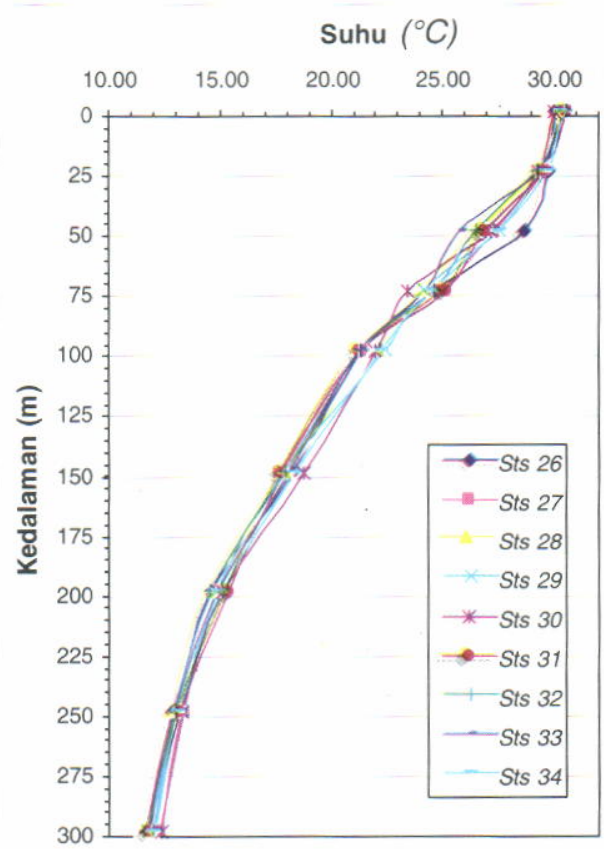

Transek 4

Gambar 3. Sebaran vertikal suhu di perairan Teluk Tomini pada bulan Juli atau Agustus 2003 (musim timur).

Figure 3. Vertical distribution of temperature in Tomini Bay on July or August 2003 (east season). (Remarks: Transect 1-2: northern part; Transect 3-4: southern part) 


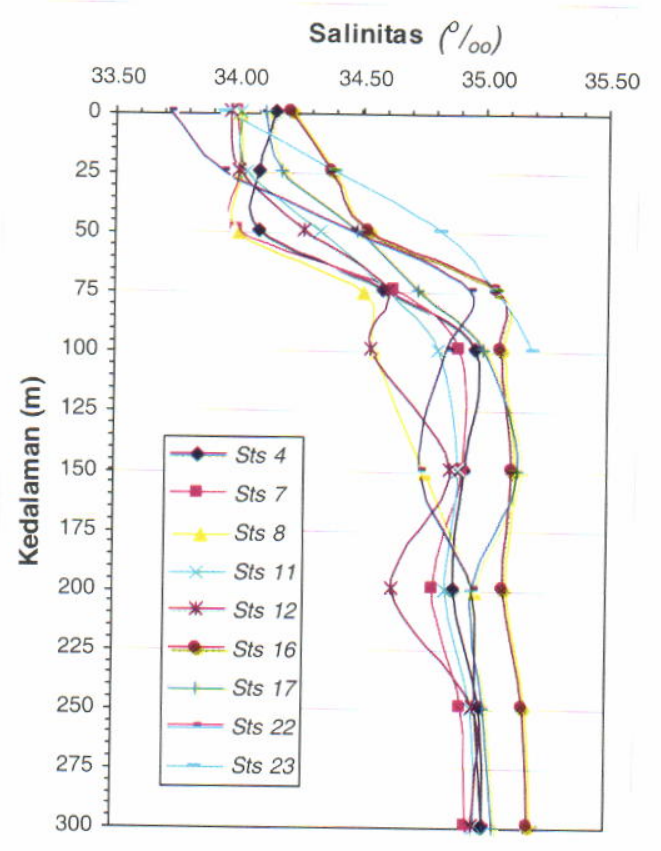

Transek 1

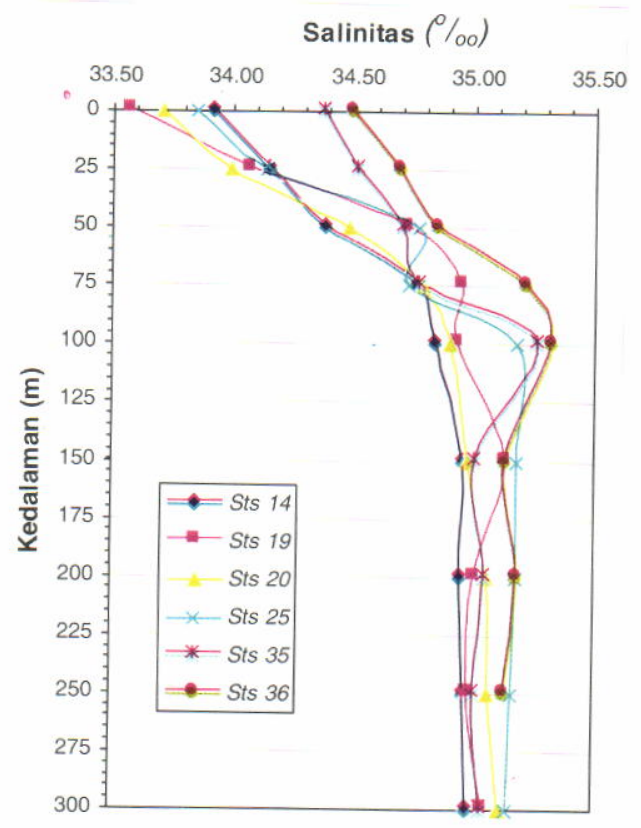

Transek 3

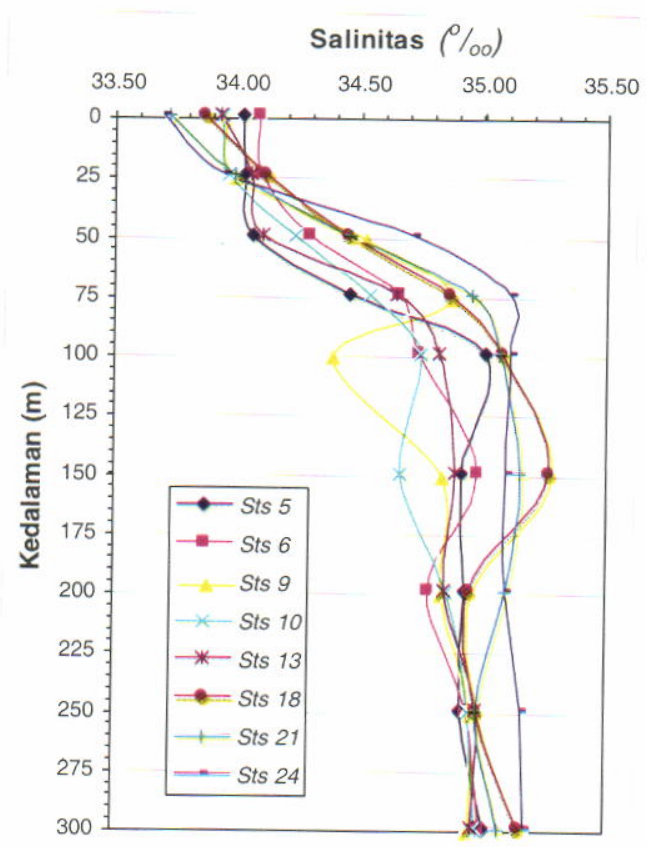

Transek 2

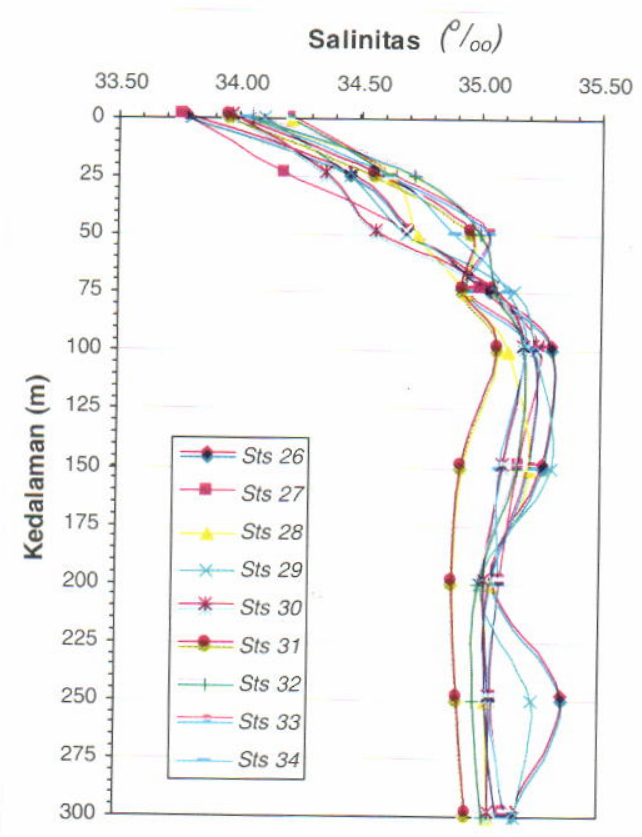

Transek 4

Gambar 4. Sebaran menegak salinitas di perairan Teluk Tomini pada bulan Juli atau Agustus 2003 (musim timur).

(Keterangan: Transek 1 dan 2: sebelah utara; Transek 3 dan 4: sebelah selatan)

Figure 4 Vertical distribution of salinity in Tomini Bay on July or August 2003 (Remarks: Transect 1-2: northern part; Transect 3-4: southern part) 
bawah $(75 \mathrm{~m}$ ). Penurunan yang cepat dari suhu di lapisan termoklin juga seiring dengan perubahan salinitas di lapisan haloklin (lihat Gambar 4).

Gambar 5 memperlihatkan pola sebaran mendaiar suhu di lapisan permukaan (0 sampai dengan $25 \mathrm{~m}$ ). Secara umum, terlihat suatu gradien suhu permukaan yang semakin hangat dari timur (sekitar mulut teluk) ke arah barat (ujung teluk). Masa air permukaan dengan suhu minimum $\left(26,8\right.$ sampai dengan $27^{\circ} \mathrm{C}$ ) mendominasi perairan sekitar mulut teluk; tetapi di kedalaman $25 \mathrm{~m}$ massa air bersuhu minimum $(27,4$ sampai dengan $27,6^{\circ} \mathrm{C}$ ) juga dominan di pantai utara Pagimana. Pola perubahan suhu permukaan demikian juga terjadi pada waktu-waktu lainnya seperti ditunjukkan oleh data citra satelit (Amri et al., 2005; pada terbitan ini); selain itu, data citra satelit juga memperlihatkan suhu permukaan laut pada bulan April sampai dengan Juni dan bulan Oktober sampai dengan Desember cenderung lebih tinggi, suhu tertinggi tercapai pada bulan Nopember sampai dengan Desember (musim barat), sebaliknya penurunan suhu permukaan mulai terjadi pada bulan Juli dan mencapai suhu terendah pada bulan September.

Gradien salinitas dalam arah yang sama (timur sampai dengan barat) juga terlihat di lapisan permukaan (0 sampai dengan $25 \mathrm{~m}$ ) seperti terlihat pada Gambar 6. Salinitas maksimum sekitar 34,15 sampai dengan 34,50 psu (warna merah) ditemukan di perairan sebelah utara Kabupaten Banggai, sedangkan salinitas minimum sekitar 33,6 sampai dengan 33,8 psu (warna biru) mendominasi perairan sekitar ujung teluk sebelah barat. Meskipun suhu relatif sama, massa air permukaan dengan salinitas lebih tinggi $(34,15$ psu) terlihat di sekitar Teluk Poso dan sebelah selatan Marisa. Di kedalaman 25 m juga nampak massa air dengan salinitas lebih tinggi $(>34,50 \mathrm{psu})$ tersebar lebih meluas hampir di sepanjang pantai utara Sulawesi Tengah, yaitu dari Parigi sampai dengan Banggai.

Karakteristik suhu rendah salinitas tinggi di perairan sekitar mulut teluk utara Banggai memberikan penjelasan adanya indikasi penaikan massa air dalam ke permukaan (upwelling) di lahan ini yang kaya nutrien serta ditandai oleh tingginya kandungan klorofil-a (indikator kesuburan perairan) seperti ditunjukkan oleh data citra satelit (Amri et al., 2005: pada terbitan ini). Menurut data citra satelit, musim timur (bulan Juli atau Agustus) diduga merupakan puncak kesuburan perairan (puncak upwelling) di daerah ini. Hasil kajian tentang sebaran kelimpahan plankton (fitoplankton dan zooplankton) dan ikhtioplankton mempertegas dugaan tersebut. Konsentrasi kepadatan plankton dan ikhtioplankton terutama tersebar di perairan sekitar mulut teluk (Awwaludin et al., 2005; pada terbitan ini; Taufik et al., 2005; pada terbitan ini). Belum diketahui secara jelas faktor-faktor yang memicu timbulnya proses upwelling di perairan ini. Tiupan angin kencang secara terus-

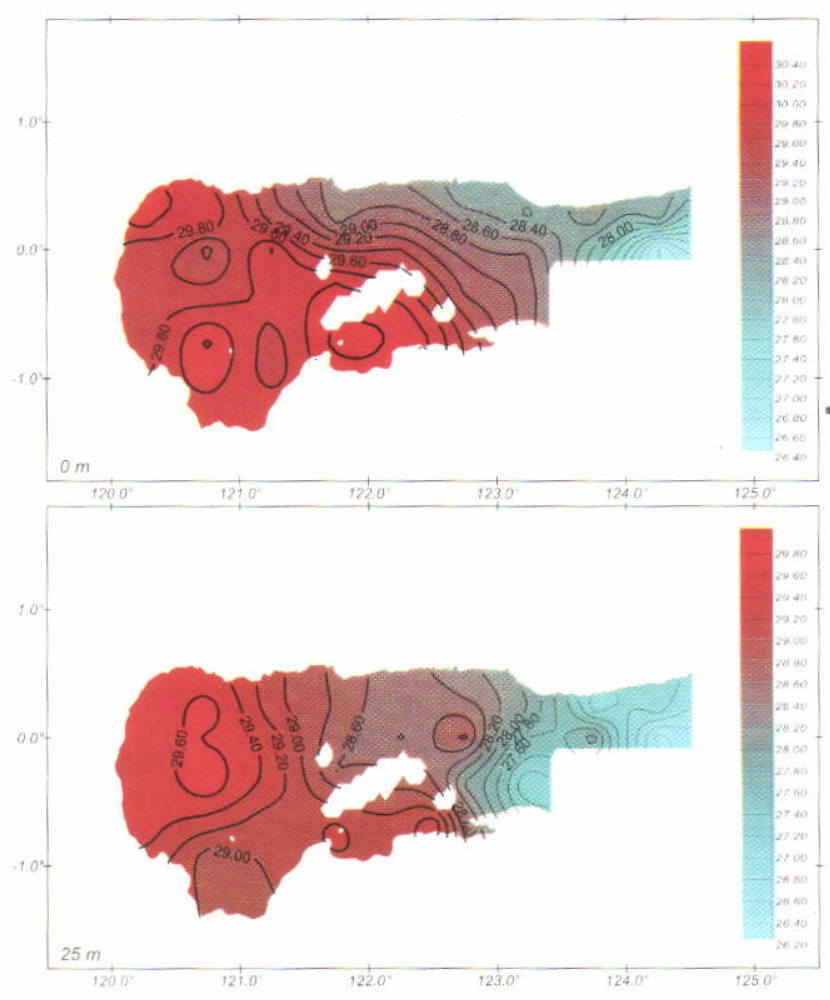

Gambar 5. Sebaran mendatar suhu permukaan pada bulan Juli atau Agustus 2003 di Teluk Tomini Figure 5. Spatial distribution of the surface temperatures on July or August 2003 in Tomini Bay. 

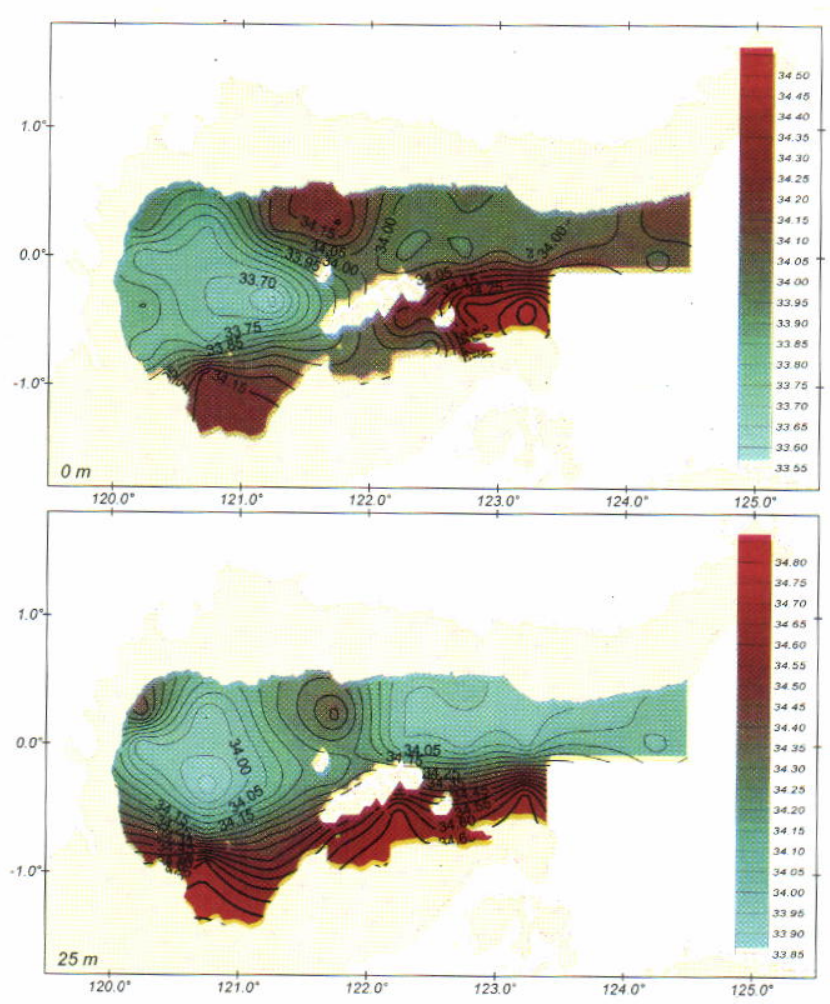

Gambar 6. Sebaran mendatar salinitas permukaan pada bulan Juli atau Agustus 2003 (musim timur) di Teluk Tomini.

Figure 6. Spatial distribution of the surface salinity on July or August 2003 (east season) in Tomini Bay.

menerus, kondisi geografi dan pola arus permukaan diduga berperan dalam proses tersebut (coastal upwelling).

Pada kedalaman $100 \mathrm{~m}$, pola sebaran mendatar suhu nampak lebih kompleks. Massa air bersuhu lebih rendah dominan di seluruh perairan terutama di sebelah utara Pagimana dan ujung teluk bersuhu minimum 21,0 sampai dengan $21,6^{\circ} \mathrm{C}$, kecuali di perairan sebelah selatan Marisa lebih hangat (suhu maksimum $23,2^{\circ} \mathrm{C}$ ). Di kedalaman 200 sampai dengan $300 \mathrm{~m}$ garis isoterm tampak lebih teratur lagi. Massa air bersuhu lebih tinggi tampak tersebar di mulut teluk, sedangkan di dalam teluk massa air bersuhu rendah lebih dominan kecuali di pantai sebelah selatan. Kompleksitas garis isohalin juga terlihat pada sebaran mendatar salinitas di kedalaman $100 \mathrm{~m}$, salinitas lebih tinggi terlihat di sebelah utara Banggai, Teluk Poso, dan di ujung teluk. Di kedalaman 200 sampai dengan $300 \mathrm{~m}$, salinitas maksimum (>35 psu) tersebar di sebelah utara Banggai dan di ujung teluk. Sebaran mendatar suhu dan salinitas di lapisan termoklin dan di lapisan kedalaman disajikan pada Lampiran 1 dan 2.

\section{Stratifikasi Massa Air dan Lapisan Gumbar (Core layers)}

Pada musim timur di lapisan permukaan diperkirakan terjadi stratifikasi massa air dalam bentuk pengadukan yang nampak lebih dominan di perairan sebelah utara (transek 1 dan 2) dibandingkan dengan di sebelah selatan (transek 3 dan 4) seperti terlihat pada sebaran melintang salinitas pada Gambar 8 . Hal ini, diperkirakan selain pengaruh musim (angin muson timur atau tenggara) dan pasang surut, terlihat indikasi adanya dorongan massa air dari lapisan yang lebih dalam ke arah permukaan di mana massa air ini memiliki salinitas lebih tinggi dan suhu rendah. Menurut Wyrtki (1961) dinamika massa air permukaan (sampai dengan kedalaman $50 \mathrm{~m}$ ) selain dipengaruhi oleh angin muson dan arus permukaan, pasang surut bertipe campuran semidiurnal (mixed tide prevailing semi diurnal) juga sangat menentukan. Berdasarkan pada oritide global tide model, pasang tertinggi di mulut teluk mencapai $+2,5$ m dan surut terendah $-2,64$ m (Burhanuddin et al., 2004).

Stratifikasi massa air juga terlihat di lapisan yang lebih dalam, di sekitar mulut teluk sampai dengan perairan di ujung teluk sebelah barat (Gambar 7 dan 8). Di sekitar mulut teluk strafikasi terjadi akibat aliran massa air dari luar teluk (Laut Maluku) yang memiliki salinitas lebih tinggi dan suhu lebih rendah. Menurut Wyrtki (1961) massa air ini berasal dari Samudera Pasifik mengalir melalui Laut Seram dan mendominasi massa air Laut Maluku. Pada musim timur, sebagian massa air tersebut mendesak masuk ke dalam Teluk Tomini. Pola arus permukaan (Lampiran 3) mempertegas hal tersebut, pada musim timur arus mengalir dari arah tenggara, di tengah mulut teluk arus bercabang 2, cabang ke-1 masuk 


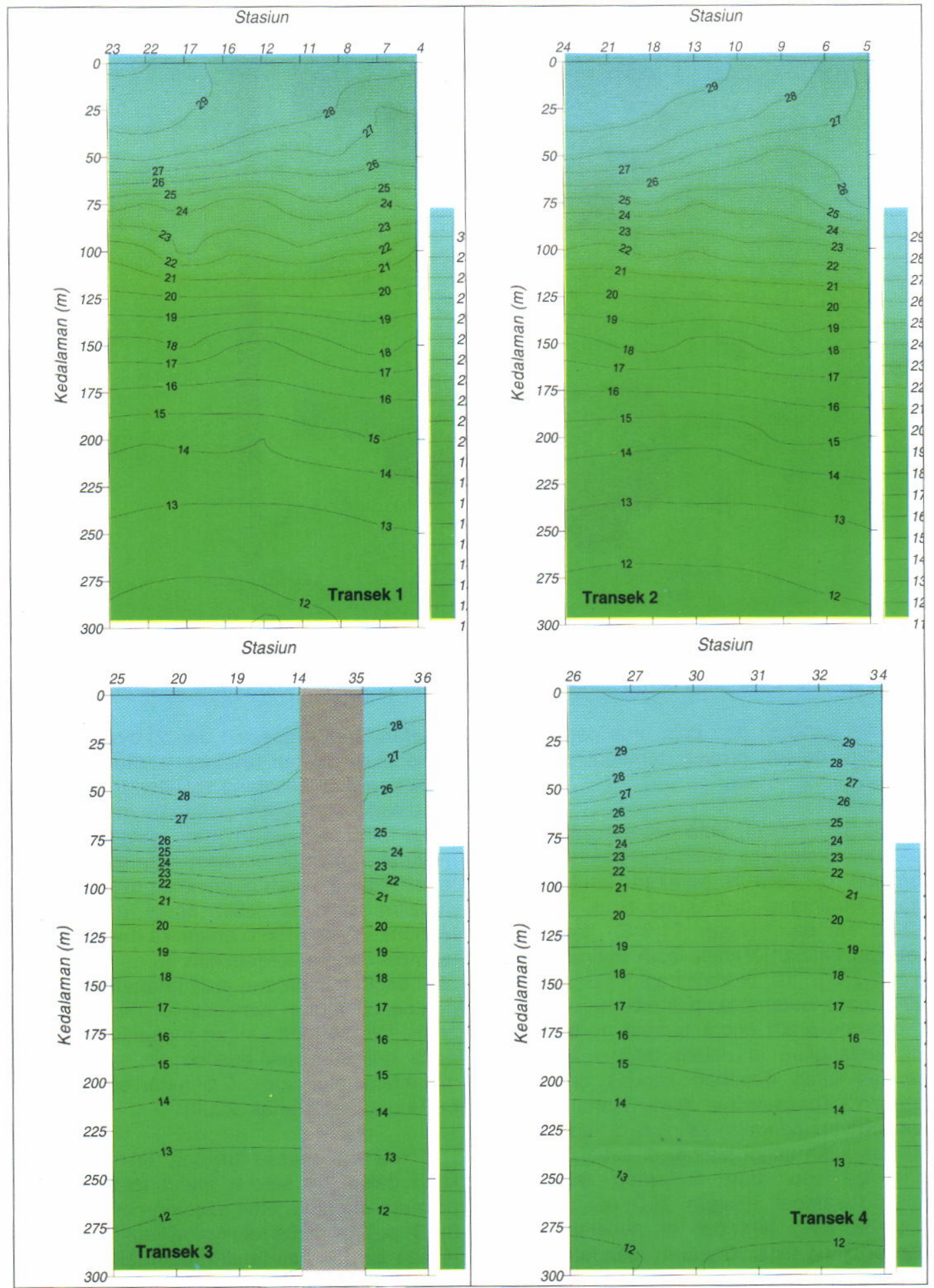

Gambar 7. Sebaran melintang suhu dalam arah barat sampai dengan timur pada bulan Juli atau Agustsus 2003 di Teluk Tomini.

Figure 7. Temperature distribution of west to east section on July or August 2003 in Tomini Bay. 


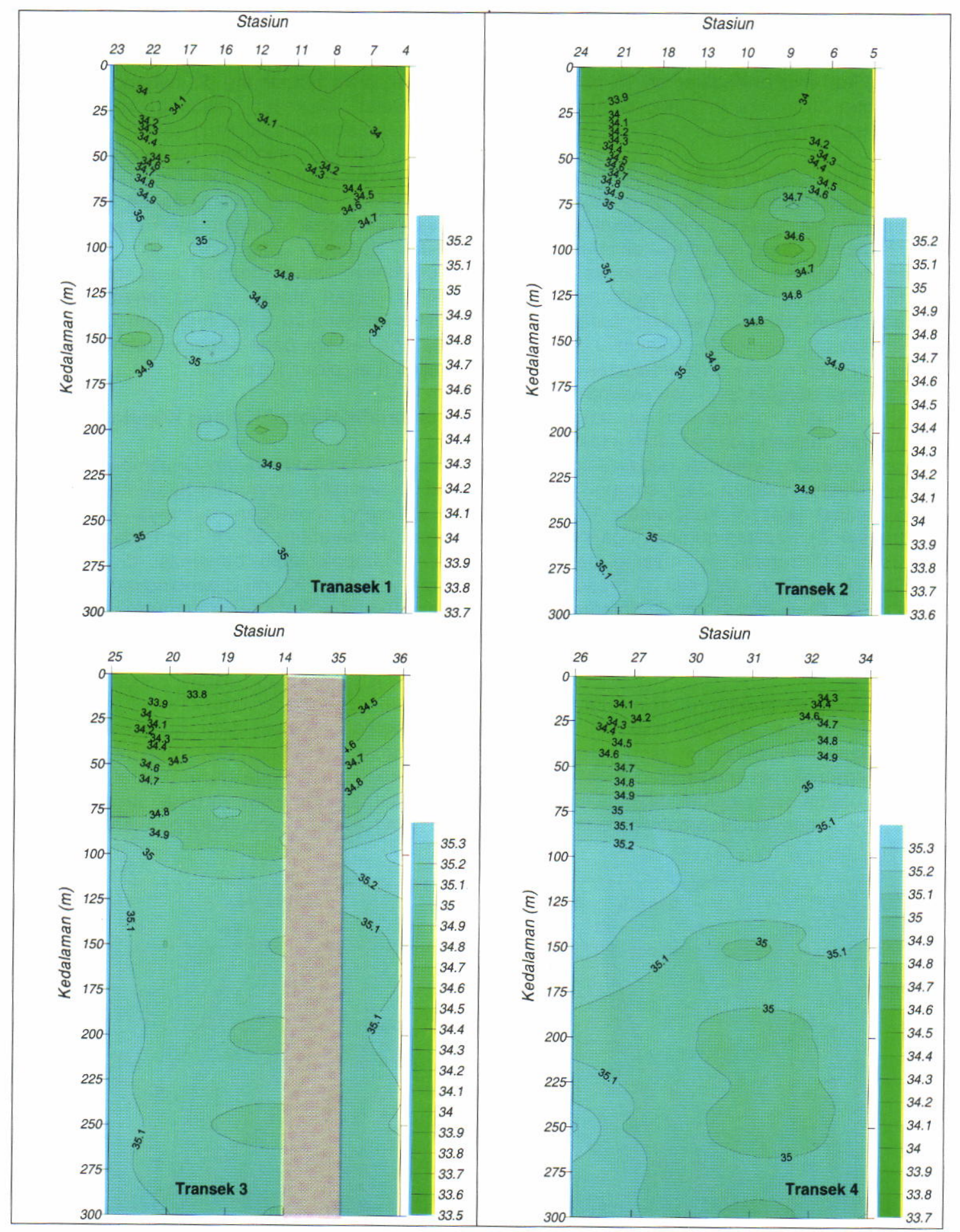

Gambar 8. Sebaran melintang salinitas dalam arah barat sampai dengan timur pada bulan Juli atau Agustsus 2003 di Teluk Tomini.

Figure 8. Salinity distribution of west to east section on July or August 2003 in Tomini Bay. 
teluk, sedangkan cabang lainnya ke utara atau timur laut. Di ujung teluk sebelah barat selain aliran massa air dari bawah nampak seolah-olah ada pembalikan massa air salinitas tinggi karena membentur daratan dan mendorong ke timur di kedalaman $75 \mathrm{~m}$ dan ke atas di kedalaman $25 \mathrm{~m}$. Hal ini, yang kemungkinan mengakibatkan isohaline miring ke atas.

Indikasi terjadinya aliran massa air yang berbeda dari luar teluk (Laut Maluku) terlihat pada munculnya lapisan gumbar (core layers) yang dicirikan oleh massa air bersuhu atau salinitas ekstrim yang berbeda dengan massa air di sekitarnya. Pada sebaran vertikal salinitas (Gambar 4), lapisan gumbar terlihat di kedalaman $100 \mathrm{~m}$ di sebelah barat mulut teluk (sebelah selatan Gorontalo, stasiun 9, transek 2), yaitu dicirikan oleh massa air bersalinitas ekstrim rendah 34,4 sampai dengan 34,5 psu (warna kuning) yang berbeda dengan massa air di sekitarnya. Indikasi munculnya lapisan gumbar lebih jelas terlihat pada sebaran melintang salinitas pada Gambar 8; massa air bersalinitas ekstrim 34,7 sampai dengan 34,8 psu ini terlihat jelas di kedalaman $150 \mathrm{~m}$ di stasiun 10 (transek 2). Lapisan gumbar juga terlihat di stasiun 12 dan 23 (transek 1), masing-masing di kedalaman 200 dan $150 \mathrm{~m}$ (salinitas $34,8 \mathrm{psu}$ ), serta stasiun 30-31-32 (transek 4) di kedalaman 175 sampai dengan $250 \mathrm{~m}$ dengan salinitas ekstrim <35 psu. Salinitas normal di kedalaman 75 m 35 psu.

Kehadiran massa air tertentu di dalam teluk pada kedalaman 100 sampai dengan $150 \mathrm{~m}$ dengan salinitas maksimum suhu minimum yang berasal dari Laut Maluku, kemungkinan merupakan arus cabang dari massa air utama yang belum diketahui dengan jelas. Wyrtki (1961) menyebutkan bahwa pada musim timur aliran massa air di perairan sebelah timur Sulawesi sangat dipengaruhi oleh arus massa air dalam (northern lower watěr), kedalaman $150 \mathrm{~m}$, yang berasal dari Samudera Pasifik. Di sebelah utara Sulawesi arus bercabang 2, cabang ke-1 ke barat arah Selat Makasar, sedangkan cabang ke-2 memasuki Laut Maluku. Arus cabang di Laut Maluku ini yang diduga memberi kontribusi besar dalam pemolaan massa air di Teluk Tomini. Perlu pengkajian lebih lanjut untuk menegaskan hal tersebut, mengingat dugaan sumber daya mesopelagis yang bersifat strong migration di Teluk Tomini dimungkinkan terkait dengan arus massa air dalam tersebut. Aliran massa air ke dalam teluk dengan salinitas maksimum suhu minimum di sekitar mulut teluk juga terlihat pada sebaran mendatar suhu dan salinitas (Lampiran 1 dan 2).

\section{Karakteristik Habitat Karang Kepulauan Togian}

Pengukuran pada bulan Desember 2004 (musim barat) di sekitar Kepulauan Togian ditemukan adanya lapisan yang homogen suhunya berada sampai dengan kedalaman $50 \mathrm{~m}$; perbedaan suhu antar stasiun tampak lebih bervariasi di kedalaman 20 sampai dengan $30 \mathrm{~m}$ dibandingkan di kedalaman lainnya (Gambar 9A). Secara umum, perairan sebelah timur dan selatan kepulauan memiliki salinitas lebih tinggi dibandingkan dengan sisi lainnya (Gambar 9B). $\mathrm{Hal}$ ini, kemungkinan akibat pengaruh massa air salinitas tinggi yang tersebar di sebelah utara Banggai dan sepanjang pantai utara Sulawesi Tengah pada musim timur. Meskipun, tidak tersedia data parameter fisik Teluk Tomini pada musim barat, sebaran suhu dan salinitas permukaan di lahan ini diduga memiliki pola yang sama, kecenderungan salinitas tinggi di
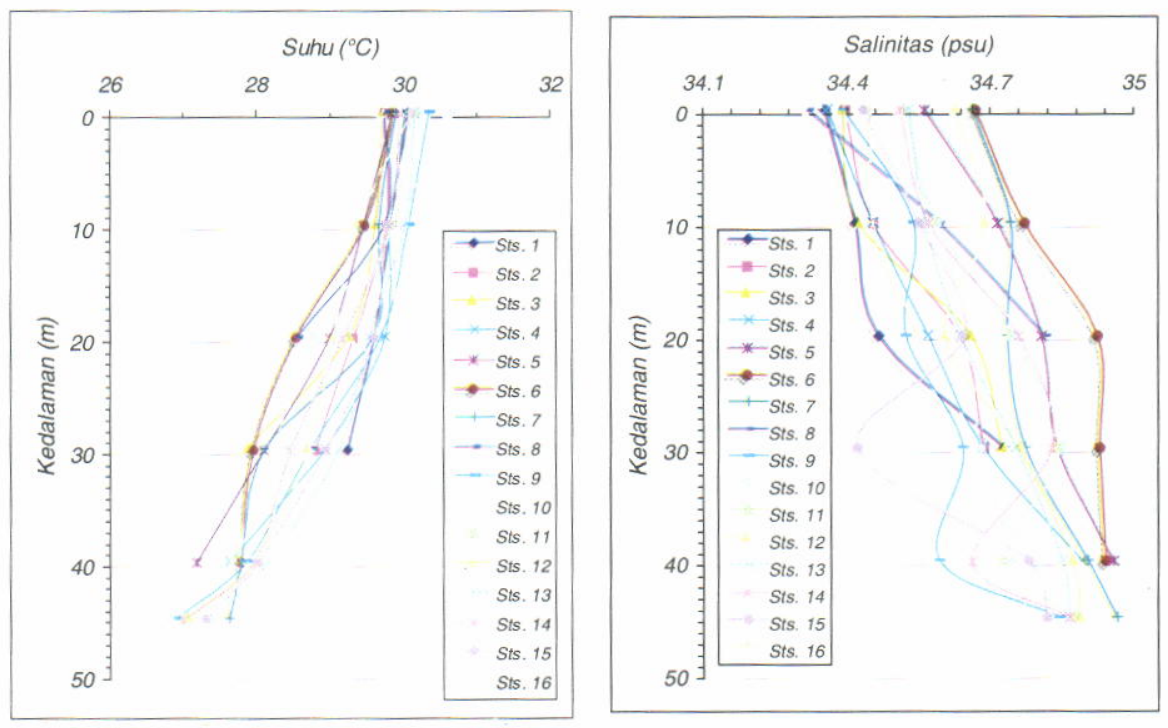

Gambar 9.

Sebaran vertikal suhu $(A)$ dan salinitas

(B) di sekitar Kepulauan Togian pada bulan Desember 2004 (musim barat).

Figure 9. Vertical distribution of temperature (A) and salinity (B) around Togian Islands in December 2004 . 

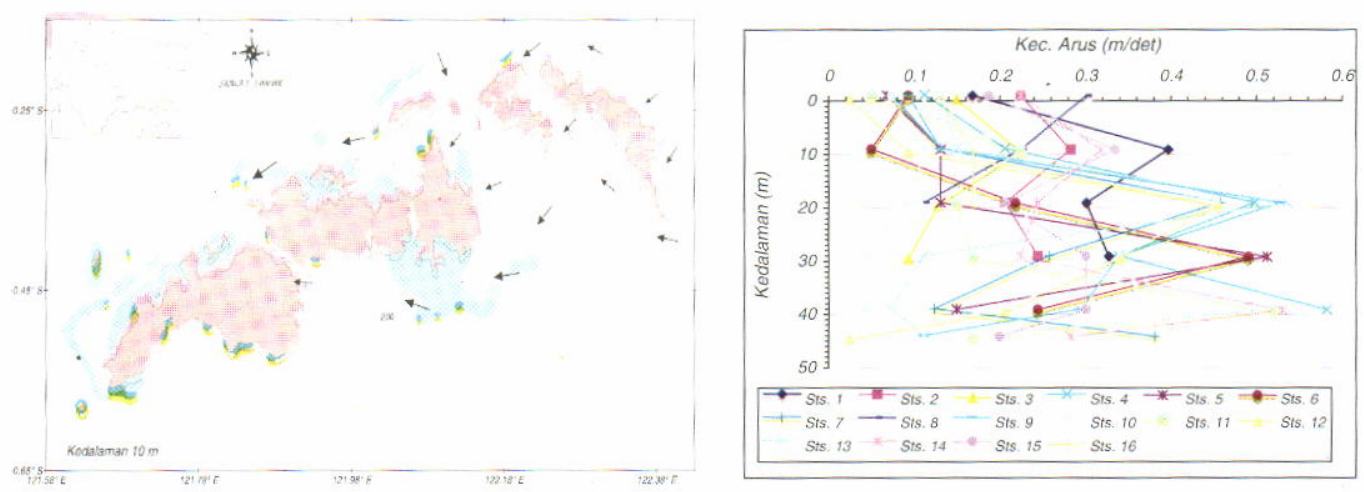

Gambar 10. Pola arus permukaan di sekitar Kepulauan Togian pada Desember 2004: (A) arus di kedalaman $10 \mathrm{~m}$; (B) variasi kecepatan menurut lokasi dan kedalaman.

Figure 10. Surface currents pattern of around Togian Islands in December 2004: (A) in $10 \mathrm{~m}$ depth; (B) currents variation is according to location and depth.

sebelah timur dan selatan kepulauan menunjukkan hal tersebut. Pola arus permukaan (kedalaman $10 \mathrm{~m}$ ) mempertegas hal tersebut (Gambar 10A).

Aliran massa air permukaan masuk kepulauan dari arah timur dan utara timur laut; pada umumnya arus mengalir ke arah barat (Gambar 10A). Arus yang mengalir di sebelah tenggara dan utara Pulau Togian cenderung lebih kencang. Variasi kecepatan arus permukaan menurut lokasi dan kedalaman dipresentasikan pada Gambar 10B. Pola arus permukaan selengkapnya menurut kedalaman ( 0 sampai dengan $50 \mathrm{~m}$ ) ditunjukkan pada Lampiran 4 .

\section{KESIMPULAN}

1. Lapisan homogen (mixed layers) pada umumnya tersebar di lapisan permukaan sampai dengan kedalaman $50 \mathrm{~m}$; di bawahnya, lapisan termoklin haloklin tersebar sampai dengan kedalaman 150 m. Lapisan termoklin haloklin tampak lebih kompleks dibandingkan lapisan homogen lainnya.

2. Terdapat gradien suhu dan salinitas di lapisan permukaan (kedalaman 0 sampai dengan $25 \mathrm{~m}$ ) dari arah timur ke barat; suhu minimum salinitas maksimum tersebar di sekitar mulut teluk utara Banggai, suhu maksimum salinitas minimum di sebelah barat (ujung teluk); suatu indikasi terjadinya proses coastal upwelling di sekitar mulut teluk (utara Banggai) pada musim timur.

3. Terdapat stratifikasi massa air di lapisan permukaan dan di lapisan yang lebih dalam. Di lapisan permukaan (di perairan sebelah utara) terlihat sebagai semacam percampuran massa air yang disebabkan selain oleh angin muson, arus permukaan dari Laut Maluku dan pasang surut, juga akibat dorongan massa air dari lapisan bawah di ujung teluk. Di lapisan yang lebih dalam (kedalaman 100 sampai dengan 300 m) stratifikasi diduga akibat masuknya massa air yang berbeda dari Laut Maluku (mungkin cabang dari massa air subtropis bawah dan massa air pertengahan utara) dan indikasi pembalikkan massa air dalam (kedalaman $>300 \mathrm{~m}$ ) karena membentur daratan ujung teluk terus mengalir ke atas dan ke timur. Keberadaan lapisan gumbar (core layers) mencirikan intervensi massa air dari Laut Maluku tersebut

4. Di sekitar Kepulauan Togian (habitat karang) massa air permukaan (kedalaman 0 sampai dengan $50 \mathrm{~m}$ ) bertipe sama dengan massa air permukaan seluruh Teluk Tomini (habitat pelagis). Terdapat aliran arus permukaan dari luar kawasan, yaitu dari arah utara timur laut dan dari sebelah timur yang diduga berasal dari pantai Sulawesi Tengah sebelah timur

\section{SARAN-SARAN}

Tipe-tipe massa air samudera di Laut Maluku (sebelah timur mulut teluk) yang diduga berperan dalam pemolaan tipe massa air Teluk Tomini belum diketahui secara pasti. Oleh sebab itu, terkait dengan dinamika sumber daya ikan pelagis yang pada umumnya bersifat strong migration serta kaitannya dengan eksistensi sumber daya di perairan lain di sekitarnya (Teluk Tolo, Laut Maluku, dan Laut Sulawesi), perlu dikaji lebih lanjut tipe-tipe massa air di Laut Maluku dan Teluk Tolo. Kajian oseanografi yang lebih luas ditujukan kepada potensi upwelling di perairan mulut teluk (sekitar Banggai) dalam kaitannya dengan proses biologi dan produktivitas perikanan.

\section{UCAPAN TERIMA KASIH}

Terima kasih kami ucapkan kepada pimpinan Balai Riset Perikanan Laut, Jakarta yang telah 
mempercayakan kepada kami melakukan riset di Teluk Tomini pada tahun 2003 sampai dengan 2004 Terima kasih juga kami sampaikan kepada Nurwiyanto, teknisi pada Balai Riset Perikanan Laut yang telah bekerja membantu dalam pengumpulan data di lapangan.

\section{DAFTAR PUSTAKA}

Amri K., Suwarso, \& Herlisman. 2005. Dugaan upwelling berdasarkan analisa komparatif citra sebaran suhu permukaan laut dan klorofil-a di perairan Teluk Tomini. Jurnal Penelitian Perikanan Indonesia Vol.11 No.6 Tahun 2005. Dalam terbitan ini. Jakarta.

Anonymous. 2001. Pengkajian stok ikan di perairan Indonesia. Pusat Riset Perikanan Tangkap. Badan Riset Kelautan dan Perikanan. Departemen Kelautan dan Perikanan. Pusat Penelitian dan Pengembangan Oseanologi. Lembaga IImu Pengetahuan Indonesia. Jakarta.

Awwaluddin, Suwarso, \& Rahmat S. 2005. Distribusi kelimpahan dan struktur komunitas plankton pada musim timur di perairan Teluk Tomini. Jurnal Penelitian Perikanan Indonesia Vol.11 No.6 Tahun
2005. Dalam terbitan ini. Jakarta.

Burhanuddin, S., A. Supangat, B. Sulistiyo, T Rameyo, \& C. R. Kepel (eds.). 2004. Profil sumber daya kelautan dan perikanan Teluk Tomini. Badan Riset Kelautan dan Perikanan. Departemen Kelautan dan Perikanan. 84 hal.

Hamilton, W. B. 1979. Tectonic of Indonesian Region. Denver, US. S. Govern. Printing office. 159-195.

Laevastu, T. \& I. Hela. 1970. Fisheries oceanography. Fishing News (Books) Ltd., London. 238 p.

Taufik, M., Suwarso, \& Nurwiyanto. 2005 Studi pendahuluan distribusi kelimpahan ichthyoplankton di Teluk Tomini dan Laut Banda. Jurnal Penelitian Perikanan Indonesia Vol.11 No.6 Tahun 2005. Dalam terbitan ini. Jakarta.

Walpersdorf, A., C. Vigny, C. Rangin, H. Bellon, \& B. Priadi. 1997. Instantaneous and Finite Kinematics in The Northern Arm of Sulawesi. Geodyssea Final Symposium. Penang. Malaysia.

Wyrtki, K. 1961. Physical Oceanography of The Southeast Asian Waters. Naga Report, Vol. 2. The Univesrity of California. California. $195 \mathrm{p}$. 
Lampiran 1. Sebaran mendatar suhu di lapisan termoklin (kedalaman $100 \mathrm{~m}$ ) dan di lapisan kedalaman di Teluk Tomini pada bulan Juli atau Agustus 2003 (musim timur)

Appendix 1. The horizontal distribution of temperatur in termoclin laye $(100 \mathrm{~m})$ and depth layer in Tomini Bay on July or August 2003 (east monsoon)
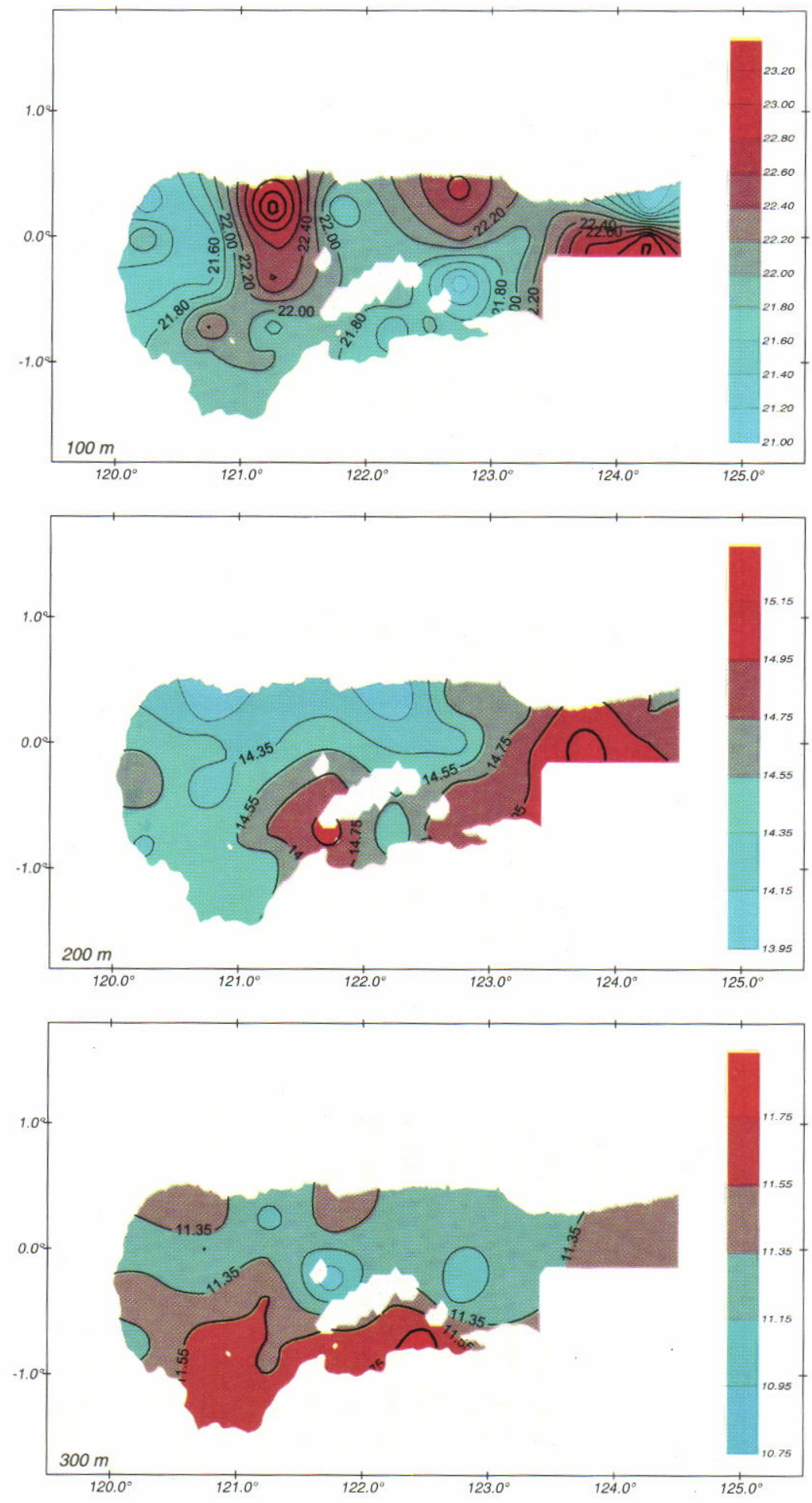
Lampiran 2. Sebaran mendatar salinitas di lapisan termoklin $(100 \mathrm{~m})$ dan di lapisan kedalaman di Teluk Tomini pada bulan Juli atau Agustus 2003 (musim timur)

Appendix 2. The horizontal distribution of salinity in termoclin layes $(100 \mathrm{~m})$ and depth layer in Tomini Bay on July or August 2003 (east monsoon)
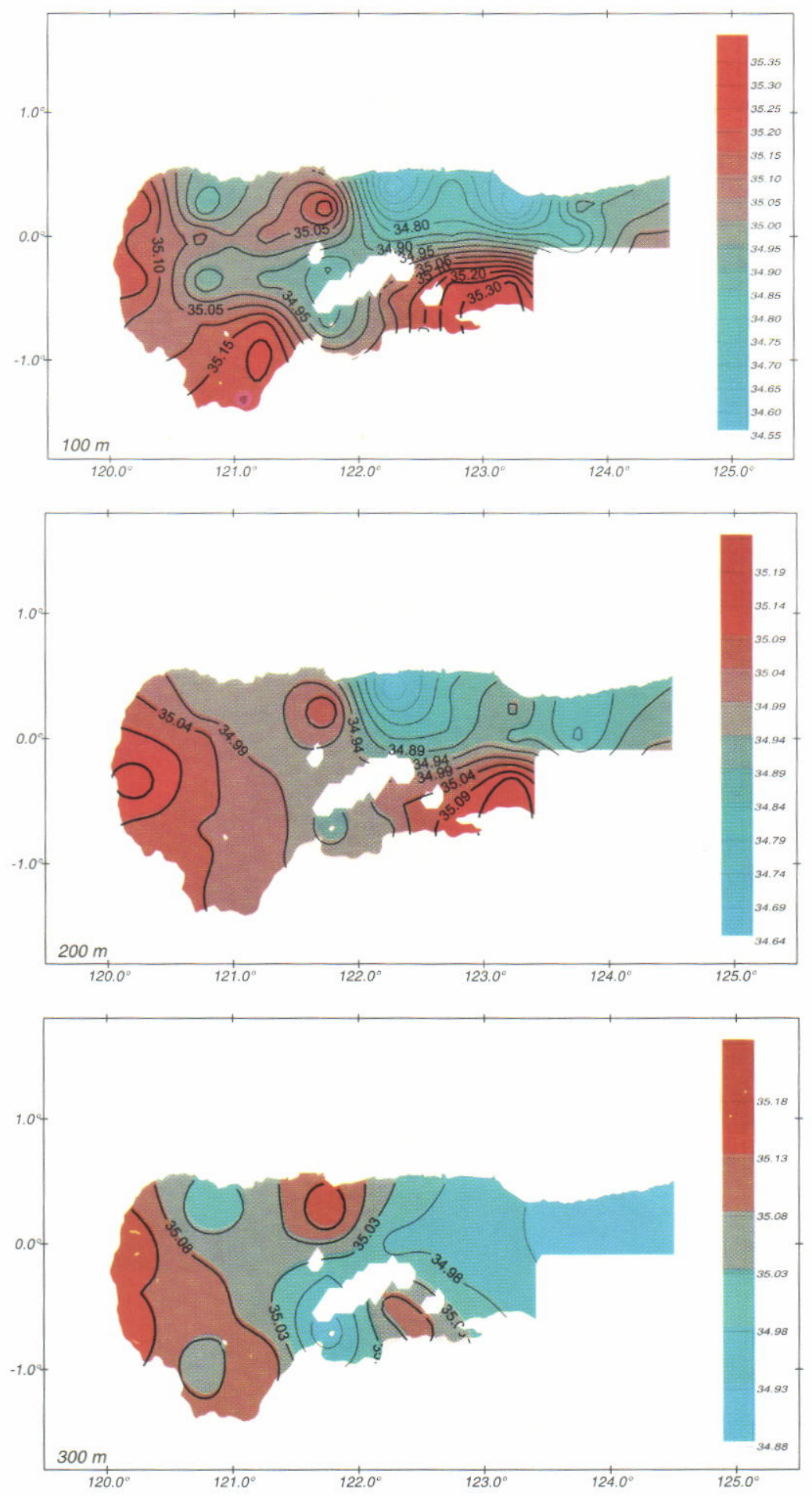
Lampiran 3. Peta arus permukaan pada musim timur di Teluk Tomini (Sumber: Safri Burhanuddin et al., 2004)

Appendix 3. The map of surface current in Tomini Bay on east monsoon (Source: Safri Burhanuddin et al., 2004)

- peta arus permukaan rata-rata bulan agustus

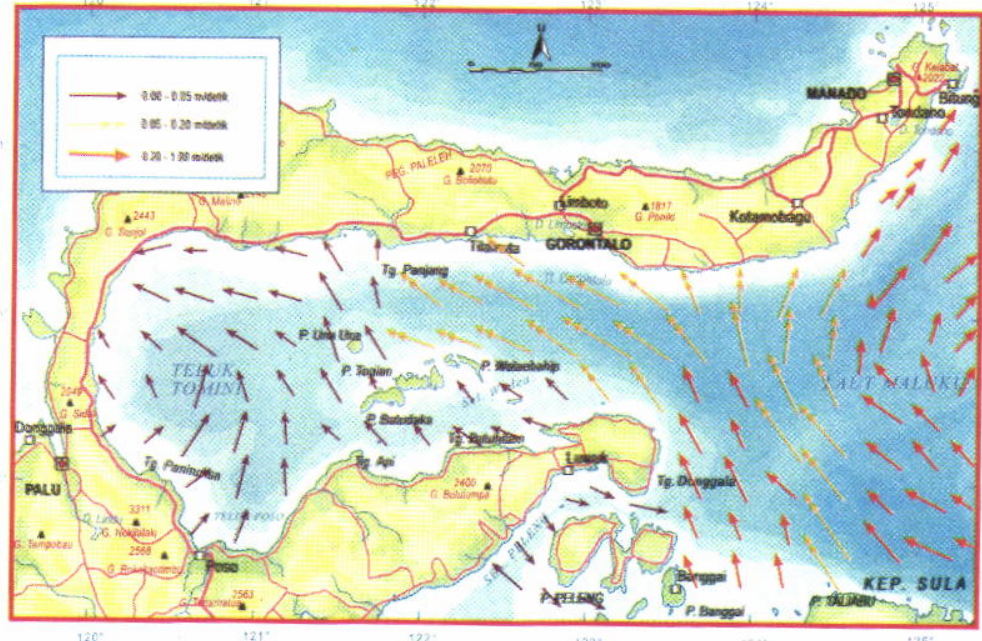

Lampiran 4. Pola arus permukaan menurut kedalaman di sekitar Kepulauan Togean pada bulan Desember 2004

Appendix 4. The model of surface current by dept in Togean Island and adjacent on December 2004

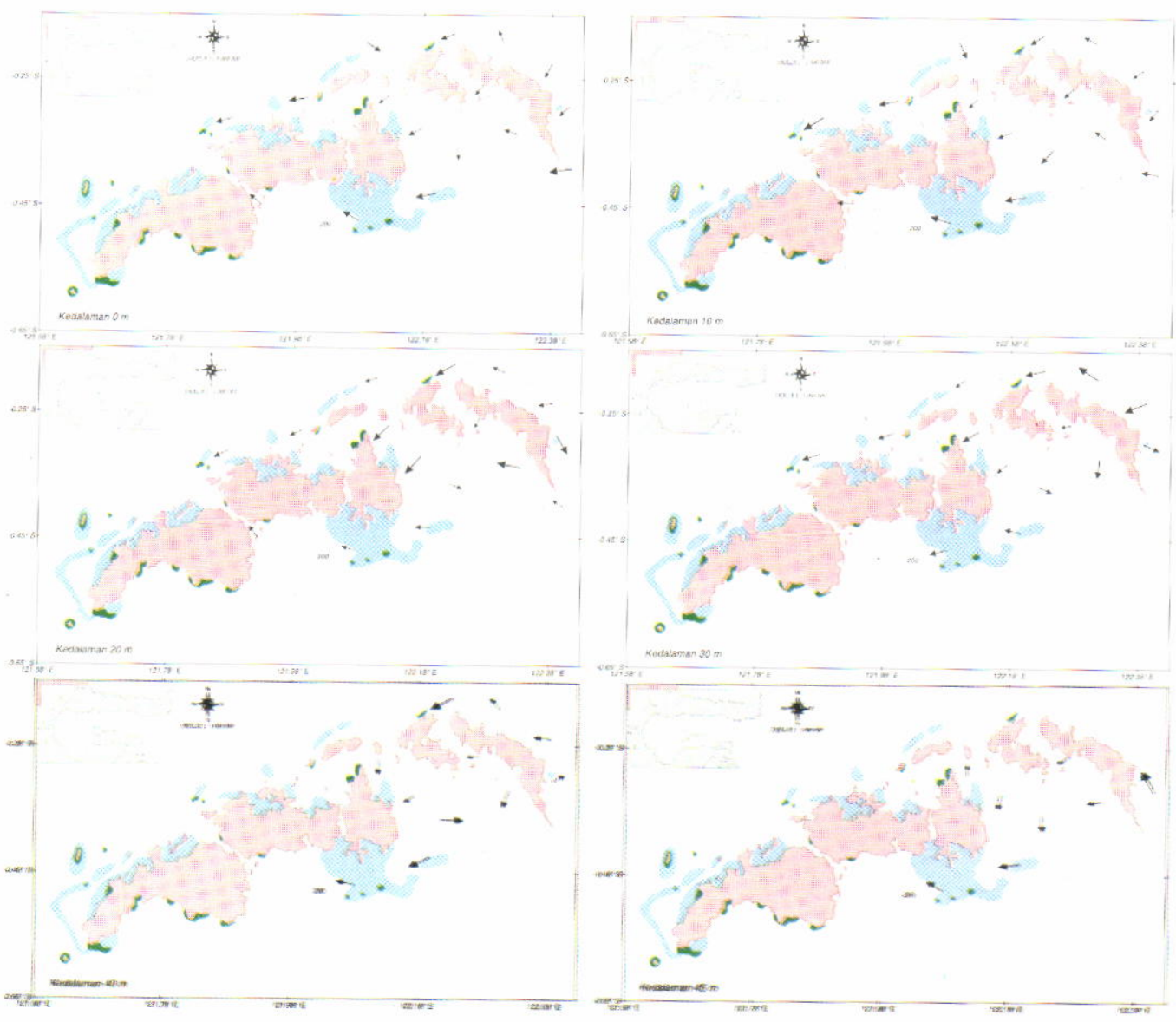


